\title{
OUTROS TEXTOS ENCONTRADOS DE MACHADO DE ASSIS ${ }^{\text {N.T. }}$
}

Jean-Michel Massa

Tradução de Lúcia Granja

\begin{abstract}
Resumo: Neste texto, publicado anteriormente apenas em francês pelo professor Jean-Michel Massa, acrescentam-se algumas peças não incluídas em seu famoso Dispersos de Machado de Assis (Rio de Janeiro, 1965). Com tradução anotada de Lúcia Granja, o texto se publica aqui pela primeira vez em português, apresentando ao leitor um pouco da produção machadiana não reunida em volume pelo autor.
\end{abstract}

Palavras-chave: Charton-Demeur; Monte Alverne; Narcisa Amália; Carnaval; Oliver Twist; Furtado Coelho.

\section{Other texts by Machado de Assis: new findings}

\begin{abstract}
In this text, previously published in French by Professor JeanMichel Massa, are included some pieces that do not figure in his famous book Dispersos de Machado de Assis (Rio de Janeiro, 1965). In this annotated translation by Lúcia Granja, the text is published here by the first time in Portuguese, and offers the reader a sample of the production of Machado de Assis never published in book form.
\end{abstract}

Keywords: Charton-Demeur; Monte Alverne; Narcisa Amália; Carnaval; Oliver Twist; Furtado Coelho.

Reunimos no Brasil, em 1962, apenas cento e cinquenta textos dispersos de Machado de Assis. Os textos que se seguem agora não puderam ser incluídos no volume Dispersos de Machado de Assis, que acaba de ser publicado no Rio de Janeiro. ${ }^{1}$ Eles foram descobertos ou localizados depois da preparação daquela coletânea e correspondem a momentos muito diferentes da carreira literária do escritor. Por essa razão, o fio condutor, às vezes em muito bom estado, que ligava um número razoável dos dispersos não pôde ser de forma nenhuma reencontrado nessas peças que tiramos do esquecimento em que jaziam há um século, ou quase, nos arquivos brasileiros.

\footnotetext{
N.T. Artigo publicado originalmente em: BOTREL, J. F.; MASSA, J-M e POUPET, A. Études lusobrésiliennes. Travaux de la Faculté de Lettres et Sciences Humaines de l'Université de Rennes. v. IX. Presses Universitaires de France.

${ }^{1}$ Dispersos de Machado de Assis. Rio: Instituto Nacional do Livro, 1965.
} 
Mas se das escavações nem sempre extraímos tesouros, os arqueólogos, grandes conhecedores da matéria, ensinam-nos que, frequentemente, essas sondagens do passado fazem surgir, diante de nossos olhos, testemunhos que são tão instrutivos como necessários à reconstituição das épocas de antanho.

Neste caso específico, a civilização desaparecida é representada por Machado de Assis, de quem se haviam, deploravelmente, negligenciado alguns vestígios significativos. É verdade que o campo para essas escavações é muito mais restrito que em 1962: o veio está em vias de extinção. Por esse motivo, a pesca está mais magra. No entanto, esses seis textos vêm completar o conhecimento que se tinha do grande escritor brasileiro. Eles serão apresentados muito brevemente aqui, pois o estudo aprofundado da maior parte deles faz parte do trabalho que publicaremos sobre Machado de Assis. ${ }^{2}$

$$
* * *
$$

$\mathrm{O}$ primeiro texto ${ }^{3}$ é dedicado à Madame Charton Demeur, uma cantora francesa, então em turnê pelo Brasil. Ela acabava de comunicar à nação a sua intenção de retornar à França em breve. Emocionado por essa decisão, Machado de Assis, que tinha então dezesseis anos e meio, endereça-lhe este poema. Ele suplica à atriz que adie sua partida, ficando um pouco ainda no Rio. O poema, que não é sem valor literário, sobretudo quando levamos em conta a idade do autor, marca também, para esse escritor, o início de certas reflexões sobre problemas estéticos.

Republicamos ainda o terceiro escrito em prosa do jovem escritor. Em 1962, apenas a primeira parte havia sido localizada. ${ }^{4}$ No entanto, para não quebrar sua unidade, apresentamos aqui o todo desse estudo sobre Monte Alverne. O jovem

\footnotetext{
${ }^{2}$ Biographie intellectuelle de Machado de Assis (1839-1870). [N.T.: O texto referido por Massa seria publicado como MASSA, J. M. A juventude de Machado de Assis (1839-1870). Ensaio de biografia intelectual. Rio de Janeiro: Civilização Brasileira; Conselho Nacional de Cultura, 1971. Uma terceira edição revista desse texto foi publicada em 2009 pela Editora da UNESP.]

${ }^{3}$ À Madame Arsène Charton Demeur, Diário do Rio de Janeiro, 7-2-1856

${ }^{4}$ Ideias vagas - os Contemporâneos - Monte Alverne. Marmota Fluminense, 4 e 6-9-1856. Cf. Dispersos de Machado de Assis, $\mathrm{n}^{\circ}$ 23, p. 33-35.
} 
escritor, agora com dezessete anos, dá seus primeiros passos na crítica literária. Monte Alverne (1784-1858) é uma figura bastante curiosa da primeira metade do século XIX. Franciscano, pregador e filósofo, ele foi o guia intelectual de alguns setores das elites brasileiras durante longos anos. Sua ação é talvez comparável àquela de Chateaubriand, no qual ele se inspira bastante frequentemente. Como o outro, ele reconciliou a literatura e a religião. Porém, em Monte Alverne, essa ação de apaziguadora concórdia, junta-se sua qualidade de homem da Igreja. Machado de Assis, na flor da idade, ficou impressionado por essa personalidade eminente, cujo desaparecimento, em 1858, marcaria uma época na evolução espiritual brasileira. Os discípulos de Auguste Comte encontrariam um campo menos entulhado. Essa meditação a respeito de Monte Alverne é um dos raros escritos em que Machado de Assis leva sua reflexão aos problemas religiosos.

O terceiro texto, ${ }^{5}$ bem como o primeiro, escapou à vigilante perspicácia de José Galante de Sousa. ${ }^{6}$ É uma obra bem diferente das duas precedentes, pois é o único poema sobre o carnaval composto por Machado de Assis. Só por esse motivo, já seria preciosa. Mas o momento que ele consagra a essa tradição tão brasileira não é sem interesse. Em fevereiro de 1860, Machado de Assis vai transpor uma fase importante de sua carreira, já que, em março desse ano, entra como redator para a equipe do Diário do Rio de Janeiro. Não é apenas um engajamento político, mas também a certeza de viver - modestamente - apenas de sua pena. Mais que isso, alguns dias depois da publicação do poema, dois bons camaradas seus, doentes há já algum tempo, iriam deixar este mundo, levados pela tuberculose que então dizimava as fileiras dos jovens poetas. Eles eram J. J. Macedo Júnior (chamado Macedinho,

\footnotetext{
${ }^{5}$ Ao Carnaval de 1860, Marmota, 21-2-1860. O primeiro e o terceiro textos que apresentamos já foram objeto de uma publicação no Brasil, no Suplemento literário do Estado de São Paulo, n 398-400, 19 e 26-09-1964, assim como 3-10-1964. Eles foram transcritos no Jornal do Brasil em 4-10-1964. Não retomamos aqui as observações que acompanhavam esses poemas. A esses dois textos, havíamos acrescentado um terceiro poema: "Núpcias", Semana Ilustrada, nº 203, 30-10-1864, que acreditávamos desconhecido. Engano lamentável pois o poema podia ser lido em uma obra de Magalhães Jr. Ao redor de Machado de Assis, 1958, pp. 84-85. Desculpamo-nos por esse engano, ainda mais porque havíamos feito algumas reservas sobre os trabalhos que o lustre acadêmico consagrou a Machado de Assis. No entanto, mantemos a restrição que fazemos em nossa Bibliografia analítica descritiva e crítica de Machado de Assis (1957-1958), 1965, p. 75, parágrafo 10, exprimindo nossa afirmação sob a forma a seguir: "RMJ atribui a M de A, com alguma precipitação, um poema etc. Como ele já é conhecido, nós não o republicamos aqui "Núpcias", que apareceu na obra mencionada. Porém, a data exata da publicação na Semana Ilustrada é 30-10-1864, e não 25-10-1864."

${ }^{6}$ José Galante de Sousa, Bibliografia de Machado de Assis, 1955. Nesse estudo, o autor enumera e localiza os trabalhos publicados por Machado de Assis.
} 
sem dúvida para ser distinguido do autor de $A$ moreninha) e F. G. Braga, o primeiro mestre de Machado de Assis. Alguns meses mais tarde, um outro amigo escritor, Casimiro de Abreu, iria juntar-se aos outros dois. O ano de 1860 foi, nesse aspecto, um tanto ou quanto sombrio. Nesse clima, este poema faz muito sentido; um hino à vida que, apesar de tudo, ali estava no momento das festas habituais do Carnaval, um retorno ao seu passado às vésperas de aceitar incumbências e novas responsabilidades. Mas pode ser que fosse apenas uma encomenda de Paula Brito...

O quarto texto é, como o segundo, um complemento dos Dispersos. ${ }^{7}$ Faltavam duas passagens à tradução de Oliver Twist feita por Machado de Assis. Publicamos uma delas, localizada em 1964. A outra parece mesmo perdida. Conservamos evidentemente os mesmos critérios que foram adotados para os Dispersos, comparando a versão portuguesa à tradução francesa (a versão de Alfréd Gérardin, Hachette, 1860), utilizada por Machado de Assis.

O penúltimo texto foi publicado em $1872 .{ }^{8}$ José Galante de Sousa o atribui a Machado de Assis. ${ }^{9}$ Nós o apresentamos somente para permitir que os especialistas julguem, sem avaliar essa atribuição. O escrito é assinado por M. Os problemas que coloca a utilização dessa inicial são demasiado vastos e numerosos para que os possamos abordar aqui, ainda mais porque o estudo da revista a Semana Ilustrada que Henrique Fleiuss fundou e dirigiu de 1860 a 1875 ainda resta a ser feito. Aliás, algumas observações sobre esse assunto também poderão ser encontradas no estudo que preparamos sobre Machado de Assis. O texto é uma breve nota crítica sobre uma poeta brasileira, Narcisa Amália dos Campos, que nasceu em 3 de abril de 1852.

O último texto é completamente inédito. ${ }^{10}$ É um bilhete de Machado de Assis a Furtado Coelho, amigo do escritor. Nascido em Portugal, esse empresário do teatro, Furtado Coelho, veio ao Rio em 1856 e foi o principal artesão da renovação que o

\footnotetext{
${ }^{7}$ Cf. Dispersos, pp. 539 e 552. Trata-se do começo do capítulo VIII, Jornal da Tarde, 5-5-1870. Por outro lado, o número de 30-6-1870 está faltando na coleção da Biblioteca Nacional do Rio. Encontraremos nos Dispersos os vinte e oito primeiros capítulos dessa tradução.

${ }^{8}$ Nebulosas, Semana Ilustrada, $\mathrm{n}^{\circ} 629,29-12-1872$.

${ }^{9}$ SOUSA José Galante de. Bibliografia de Machado de Assis, p. 445.

${ }^{10}$ Carta de Machado de Assis a Furtado Coelho (22-11-1876). Podemos ler novembro ou fevereiro no manuscrito. Essa carta está na Biblioteca Municipal de São Paulo, setor de manuscritos, e figura ali no nome de Machado de Assis. O texto parece ter escapado até agora da vigilância dos paulistas.
} 
teatro brasileiro conheceu à época realista. Sobretudo após a morte de João Caetano, em 1863, data que marca também, aproximadamente, o fim do período romântico no teatro, Furtado Coelho teve liberdade de agir. Mas, mesmo antes dessa data, Machado de Assis colaborava frequentemente com ele, fornecendo uma parte dos textos de seu repertório.

Não se sabia que após 1870 o escritor continuava a ajudar esse empresário. O bilhete apresenta-nos, ao mesmo tempo, um enigma. Na verdade, após algumas linhas, Machado propõe-lhe duas oitavas, que deviam completar uma peça hoje perdida. Talvez se trate de um acréscimo ou modificação à paródia de A Traviata, representada no Brasil em 1873, e que parece ter sido retomada em $1876 .^{11}$ Se essa hipótese é verdadeira, seria o único fragmento da peça que teria sido conservado. $\mathrm{O}$ que quer que seja, podemos deduzir dessa peça que Machado de Assis não havia abandonado completamente o teatro em 1876. Aliás, não temos a intenção de revisitar esse assunto proximamente.

Assim, esse textos, um pouco heterogêneos, de valor e interesse muito desiguais, reunidos aqui um pouco por acaso, completam, sob pontos de vista diversos, o conhecimento que se tinha desse grande escritor brasileiro.

$* * *$

\section{A MADAME ARSÈNE CHARTON DEMEUR}

Heroína da cena, que entre as flores

Que a senda esmaltam da carreira d'arte

Em que orgulhosa pisas, ostentando

A fronte além das sombras que forcejam

Debalde por calcar teu nome e glória,

Colhes coroas mil com que te adornas,

Benévola me escutas. Eu sou bem fraco,

Mas poeta me creio, se o teu nome

\footnotetext{
${ }^{11}$ SOUSA, José Galante de. Bibliografia de Machado de Assis, p. 469-470. O nome dessa paródia é Cenas da vida do Rio de Janeiro.
} 
Na lira acordo que meu peito exalta!

Que val o templo, se lhe falta o nume?

Não nos fujas daqui, Charton divina!

Deserto fica o majestoso alcáçar

Que Verdi exalta com florões de glória!

Deserta a cena onde pisaste, ornando

A fronte altiva de lauréis, de flores,

Em face a um povo que aplaudindo o gênio

Com palmas estrondosas, tinha mostrado

Quanto estima o talento, quanto te ama!

Deserto o nosso espírito de gozos,

Suaves sensações que o ser enlevam;

Da tua bela voz ermo de influxos,

Repercutindo apenas dentro d'alma

Os ecos do teu canto sonoroso,

A cada som pungindo uma saudade!

Oh! sol que o céu das artes iluminas,

É cedo o ocaso teu na nossa terra!

Um dia mais, um dia mais de enlevos;

Fica Charton, - contigo a luz gozamos;

Sem ti - sombria treva a cena envolve!

Anjo de melodias, quem soubera

Imitar de teu feito - harpa celeste -

O meigo som, para louvar num hino

'Teu canto que tu mesma hás já louvado!

Quem me dera, Charton, sentir na mente

De Alfredo de Musset o gênio em chamas

De imenso ardor, para com voz altiva

Levantar-te um padrão, mais duradouro

Que o mármor ou que o bronze, que lembrasse

Junto do nome teu meu nome obscuro!

Mas não posso obter do austero fado

Glória maior que admirar-te o gênio 
Num pobre canto, que o teu canto inspira!

Musa gentil dos versos que ora teço,

Quando longe de nós, lá noutro palco,

Traduzindo as de Verdi obras sublimes,

Outros mortais que anelam ver teu rosto

E ouvir teu canto cheio d'harmonias,

Com meiga e doce voz extasiares,

Recorda o canto meu - recorda o vate,

Que mais que todos te admira o canto,

Talento e garbo que ostentas na cena!

Não mais minh'arpa! - Inda uma vez te peço,

Não nos fujas daqui - Charton divina!

Inda uma vez de teu talento o brilho

Esparge sobre nós, que eu te asseguro

Não nos falece o santo entusiasmo

Com que já te acolhemos!

Grande eterno,

Refulge o nome no altar da Glória!

Grande é Stoltz, mas Stoltz há muitas;

Charton só uma, que no mundo impera!

Rio de Janeiro, fevereiro de 1856.

Joaquim Maria Machado de Assis.

(Diário do Rio de Janeiro, 7-3-1856)

$* * *$

FOLHETIM

IDEIAS VAGAS

Os Contemporâneos

Monte Alverne 
A humanidade flutua entre dous pontos totalmente opostos: - o bem e o mal -. Os sectários do mal são os inimigos declarados da virtude; são os viciosos, esses que têm uma crença por necessidade e não por convicção, para quem o nome de Deus é uma expressão vulgar e à qual se não deve respeito algum. Os sectários do bem são os adversários do vício: são os virtuosos, em cujo coração convicto se aninha a fé e a crença com todo o ardor e pureza, com todo o respeito e entusiasmo.

Ora, o bem e o mal são dois caminhos diversos no aspecto e no termo; o primeiro é cheio de abrolhos; o segundo, de flores: no fim do primeiro há flores; no do segundo, espinhos. As almas fracas, as naturezas superficiais deixam-se levar pelas aparências, e, trilhando a senda do mal, aspiram o perfume venenoso dessas flores que vegetam debaixo de seus pés; os espíritos profundos e filosóficos, observadores dos dogmas sagrados, lançam-se ao bem e enxugam nas flores do termo do seu caminho o sangue vertido de seus pés pelo contato dos espinhos.

Se não tivera de escrever as minhas ideias tão rapidamente, eu evocaria as veneráveis sombras daqueles mártires da Idade Média, mártires pela fé, e pelo dogma, cuja história tão sanguinolenta foi cantada pelo imortal Chateaubriand. Evocaria, porque vou falar de um homem tão crente, tão resignado, tão virtuoso, como os ilustres batalhadores cruzados que nas épocas calamitosas da Cristandade deram seu sangue a prol da religião. Mas essa evocação poder-me-ia levar insensivelmente a reflexões por demais longas, e é força que eu seja breve, muito breve.

E, pois, duas palavras podem servir para uma invocação:

- Religião, inspirai-me!

A eloquência, da tribuna profana, está muito aquém da do púlpito. Cícero, o maior eloquente da Antiguidade, é menos que Bossuet, porque no mundo profano os espíritos apaixonados defendem os seus interesses e as suas opiniões; no mundo religioso, há só um ponto fixo onde estão todas as vistas, e à roda do qual se volvem todas as ideias; esse ponto é grande e sublime, e se se falar dele com a mais simples linguagem, isso mesmo será eloquente.

Mont'Alverne é um nome de uma extensão infinita, que desperta em nossos corações as sensações mais profundas, o entusiasmo mais férvido, porque - Mont'Alverne - quer dizer - uma glória do Brasil, um primor do púlpito, um Bossuet nascido nas plagas brasileiras e inspirado na solidão do Claustro!

Vede-o no fundo de uma cela sombria e humilde, pálido e abatido pela idade e pelos sofrimentos; vede-o ali com a mais severa humildade. É um inspirado de Deus. Mas infeliz! Em vão seus olhos procuram ver a luz do sol; estão fechados para sempre! Só a luz do 
gênio, uma lâmpada erguida num santuário, ilumina aquele espírito tão sublime, tão admirável como esse círculo de fogo, que brilha constante no universo!

Olhai-o! Contemplai aquela nobre fronte empalidecida pelos anos, e pela disciplina, iluminada pelo gênio e pela fé; deixai-vos impressionar por todas as ideias que essa contemplação vos lançar na imaginação, e reconhecei nele o homem virtuoso, eloquente, admirável, a expressão mais sublime da grandeza de Deus!

Falai-lhe, procurai ouvir-lhe aquela voz eloquente e poderosa, ouvi-lhe aquelas frases, pesai bem a sublimidade de sua linguagem; e se quando penetrastes naquele retiro, levastes o ceticismo no coração, trareis, no sair dele a crença e a fé, porque a eloquência daquele homem sagrado convence ao cético da existência de Deus, e planta a fé na alma do ateu!

Um apóstolo de Cristo, pregando e convencendo as turbas da sua existência, não lega a Deus só a sua alma, ele lhe dá também mil outras, que com a sua palavra faz entoar no grêmio da fé e do Catolicismo! E pois: quantos corações, alentados por uma crença duvidosa, ou totalmente descrentes dos dogmas sagrados, não se terão convertido ao ouvir a sublime linguagem daquele Apóstolo sagrado?

Mont'Alverne, o homem eloquente e virtuoso, cuja vida se tem passado na austeridade e solidão do Claustro, é uma prova da solidez dos nossos princípios religiosos! Se o seu horizonte material acaba na parede sombria de uma cela humilde, os seus limites intelectuais chegam até Deus, isto é, perdem-se no infinito!

La na época de sua mocidade, no verdor de seus anos, quando a palavra saiu-lhe dos lábios forte e sonora, porque no peito o gérmen dela girava-lhe ainda o sangue juvenil e ardente, que lhe aviventava as esperanças; lá na época de sua aurora claustral, Mont'Alverne, esse que hoje se acabrunha debaixo do peso dos anos, era a ideia mais viva de todos, era a celebridade do dia, era um homem em quem todos pensavam, era o nome que todos proferiam, porque então frequentando a tribuna de orador sagrado, ele fazia ouvir as suas palavras eloquentes, como verdadeiras, tão sonoras quanto sublimes!

Imaginai que um templo está apinhado de povo, que este povo se agita estrepitosamente, que entre ele um nome corre na boca de todos, de sentido em sentido, de coração em coração, que esse nome voa de uma extremidade a outra com a rapidez do pensamento; imagina-se depois que, além destas cabeças revoltas e agitadas, surge na tribuna sagrada um homem de hábitos monásticos, em cujo olhar radiante brilha o fogo da inspiração, e em cuja fronte, iluminado pela crença e pelo gênio, se vê o selo da virtude. Pois bem, esse nome que se repetia entre o povo, e esse homem que se levanta do púlpito, é - Mont'Alverne! 
$\mathrm{O}$ mais religioso silêncio sucede àquele rumor que agitava as turbas; todas as respirações se contraem, todos levam a mão ao coração, como para evitar as suas pulsações, os olhares, os pensamentos e os espíritos fixados nele esperam ouvir-lhe a voz eloquente, já muitas vezes ouvida, mas ainda não bastante para saciar-lhes o desejo. $\mathrm{O}$ anjo das inspirações desce então ao seu espírito, ele abre os lábios e profere as primeiras palavras... a comoção se pinta em todos os semblantes... Diríeis Moisés falando ao povo de Israel...! Sua voz divina começa a soar no recinto do templo; sua alma desprende-se do corpo e arrebata-se até Deus; suas palavras gravam-se na memória de todos; em todos os corações acham um eco, em todas as consciências plantam uma convicção! É que na tribuna sagrada aquele apóstolo de Cristo não define sentimentos que não sinta, não ensina virtudes que não pratica; ele é o exemplo, é a personificação da crença e da virtude, e por isso sua voz sublimada pela verdade, cimentada pela filosofia da religião, é um brado das suas convicções, é a voz do homem eloquente, do homem filósofo, do homem consciencioso, que todas se fundam no homem crente.

Mont'Alverne, com a sua voz, criou a sua reputação; é a ela, é à sua eloquência, que ele deve o seu nome e a sua glória! Todavia, sem que a vaidade o cegasse, sem que a ambição o dominasse, ele pregou e falou às multidões entusiastas que o aplaudiam, não como quem queria alcançar a posteridade, mas como quem falava como consequência de sua vocação.

Mont'Alverne é uma forte coluna do catolicismo, é uma glória do púlpito; junta a prática à teoria, a ação à reflexão, adota os princípios morais e tendentes ao bem: tem a virtude e a humildade estampadas no semblante envelhecido pela idade e pela disciplina monástica; nele temos a admirar uma honrosa exceção das tendências viciosas que desgraçadamente mancham o sacerdócio no século atual.

Ao terminar essas mal traçadas ideias, peço desculpa ao ilustre Apóstolo da igreja, se ofendi a sua humildade com os encômios que teci (assaz merecidos). Não pude deixar de ceder a um desejo de imaginação.

De Mont'Alverne pode dizer-se o mesmo que Lamartine disse falando de Bossuet: - Não é um homem, é um oráculo.

A Marmota $\mathrm{n}^{\circ}$ 768, 769, 4 e 6-9-1856.

$$
* * *
$$

Declaração: 
Temos o prazer de anunciar aos nossos leitores que o Sr. Machado de Assis faz hoje parte da colaboração da Marmota.

AO CARNAVAL DE 1860

\section{A MARMOTA AOS SEUS LEITORES}

Morreste, seriedade!

Momo, o deus das zombarias,

Usurpou-te, por três dias,

Teu esplêndido bastão!

De um exílio temporário

Toma a longa e nova rota;

Agora reina a chacota

E o Carnaval folgazão!

Diante das aras da rubra folia,

Cabeça a mais séria não vale um real;

Doidice, festança e alegria,

Tudo isto é fortuna que traz - CARNAVAL.

Homem sério e bem formado,

Neste dia é contrabando;

Respeitado e venerando

É coisa que não se diz;

A razão abrindo os lábios,

Onde tem berço o juízo,

Vestiu um chapéu de guizo,

E pôs um falso nariz!

Nem pai de família, nem velho empregado,

Doutor, diplomata, caixeiro ou patrão,

Ninguém, ó loucura, no dia aprazado,

Não pode negar-te seu grande quinhão.

Tudo a loucura nivela,

Nem há luta de inimigos: 
Esqueçam-se ódios antigos

De algum ferrenho eleitor;

Há tréguas por três dias

No campo dos candidatos,

Que o feijão ferve nos pratos

E os guizos falam melhor.

Esqueça-se tudo, são todos convivas,

Os ódios se apaguem no abraço comum:

Que doce batalha! Que lutas festivas!

Daqui deste campo não foge nem um!

Todas as belas amáveis

Podem ter parte na festa:

Sacerdotisas e Vesta,

Acendei os corações!

Pra sustentar a empresa

Não tendes armas faceiras?

É não tirar as pulseiras

E conservar os balões.

Daí das janelas olhando curvadas.

Sem dar um só passo na luta venceis:

Ao fogo, que corre das vossas sacadas

Aquiles se curvam e algemam-se reis.

Os reis, conquanto pintados,

Sempre são reis por três dias;

E sabem as galhardias

Das vossas armas leais.

Nós somos a Roma Inerte

Com a invasão peregrina

Que os hunos de crinolina

São mais que os outros fatais.

A Marmota, $\mathrm{n}^{\circ} 1136,21-2-1860$ 


\title{
OLIVEIRO TWIST
}

\section{Capítulo VIII}

\author{
Capítulo VIII
}

\section{UM RAPAZ MISTERIOSO}

\section{OLIVEIRO VAI A LONDRES E ENCONTRA EM CAMINHO}

Chegando ${ }^{12}$ ao fim do atalho, achou-se Oliveiro na grande estrada. Eram oito horas; e, posto que estivesse já a cinco milhas da cidade, correu e escondeu-se por trás de uma cerca até meio-dia; ${ }^{13}$ assentou-se num marco de pedra, ${ }^{14}$ e pela primeira vez entrou a considerar que lugar escolheria para ganhar a vida.

O marco ${ }^{15}$ indicava, em letras grossas, que a cidade de Londres ficava a setenta milhas; o nome Londres despertou no espírito do menino uma série de ideias. Não poderia ele ir a Londres, a cidade imensa, onde nem o Sr. Bumble viria a descobri-lo? Oliveiro ouvira sempre dizer aos velhos mendigos do asilo que um rapaz de juízo nunca ficava desamparado em Londres, e que havia nessa grande cidade meios de existência desconhecidos à gente do campo. Era esse o lugar que convinha a um rapaz sem asilo, destinado a morrer na rua, se lhe não dessem a mão.

${ }^{16}$ Oliveiro levantou-se e continuou viagem.

Andou mais quatro milhas, ${ }^{17}$ sem pensar no que devia sofrer antes de chegar a Londres; como essa ideia lhe surgisse ao espírito, atrasou o passo e pôs-se a pensar nos meios de lá chegar.

Tinha no embrulho que levava um pedaço de pão, uma camisa velha, dois pares de meias, e na algibeira um penny que lhe dera o Sr. Sowerberry depois de um enterro em que se distinguira na alta qualidade de urubu.

- Não é mal, pensava Oliver, ter uma camisa lavada, dois pares de meias, e um penny; mas é escasso recurso para viajar sessenta e cinco milhas a pé durante o inverno.

\footnotetext{
12 Não traduzido: à la barrière.

${ }^{13}$ Não traduzido: dans la crainte d'être poursuivi et rattrapé.

14 "Num marco de pedra" traduz "près d'une borne pour se reposer".

${ }^{15}$ Não traduzido: au pied de laquelle il était assis.

${ }^{16}$ Não traduzido: tout en se laissant aller à ces pensées.

17 "Andou mais quatro milhas" traduz "il diminua encore de quatre bons milles la distance que le séparait de Londres".
} 
Oliveiro tinha, como muita gente, fácil penetração para descobrir as dificuldades, e lenta ${ }^{18}$ inteligência para achar os meios de a remover; de maneira que, depois de refletir muito, sem achar a solução que procurava, pôs o embrulho às costas e continuou a andar.

Nesse dia andou 20 milhas sem comer outra coisa além do pedaço de pão e alguns copos d'água que pediu à porta das cabanas. De noite, entrou em um campo, deitou-se ${ }^{19}$ ao pé de um moinho ${ }^{20}$, resolvido a esperar ali o dia. Ao princípio teve medo, ouvindo o assobiar $^{21}$ do vento; sentia frio e fome; mais que nunca estava desamparado; contudo o cansaço fê- lo dormir e ele esqueceu tudo.

De manhã, ao levantar-se, sentiu as juntas presas por causa do frio, e tinha tanta fome que comprou um pouco de pão com o penny, na primeira aldeia que atravessou. Quando chegou a noite tinha andado doze milhas; estava com os pés inchados e as pernas tão fracas que tremiam; a segunda noite que passou ao relento ${ }^{22}$ quebrou-lhe totalmente as forças.

Não podia andar; esperou, ao pé de uma ladeirinha, que passasse alguma diligência, e pediu esmola aos passageiros da almofada, ${ }^{23}$ ninguém fez caso dele; os que o viram disseram-lhe que esperasse que a diligência chegasse ao alto, e que lhes mostrasse quanto tempo era capaz de andar para ganhar meio penny. O pobre Oliver tentou acompanhar a diligência, mas não pôde; então os passageiros da almofada puseram o meio penny na algibeira, dizendo que Oliveiro era um vadio. ${ }^{24}$ A diligência desapareceu no meio de uma nuvem de poeira.

${ }^{25}$ Se não fora a boa alma de um guarda-barreira, a caridade de uma velha, os sofrimentos de Oliver seriam abreviados como os de sua mãe, isto é, morreria o pequeno na estrada. Mas o guardabarreira, ${ }^{26} \mathrm{e}$ a velha, cujo neto naufragara e errava em alguma

\footnotetext{
${ }^{18}$ Não traduzido: et paresseux.

${ }^{19}$ Deitou-se traduz se blottit.

20 "Ao pé de um moinho" traduz "au pied d'une meule de foin".

${ }^{21}$ Não traduzido: tristement.

22 "Ao relento" traduz "à la belle étolle, par un temps froid et humide".

23 "Da almofada" traduz de "l'impériale".

${ }^{24}$ Não traduzido: qui ne méritait rien.

${ }^{25}$ Não traduzido: Dans quelques villages, de grands poteaux étaient plantés sur la route, et portaient un écriteau annonçant que quiconque mendierait serait mis en prison; cet avis effrayait beaucoup Olivier et il s'éloignait au plus vite. Ailleurs, il s'arrêtait devant le cours d'auberge et regardait piteusement ceux qui allaient et venaient, jusqu'à ce que l'hôtesse donnât l'ordre à un des postillons qui flânaient dans la cour de chasser cet étrange garçon qui restait là, sans aucun doute, dans l'intention de dérober quelque chose. S'il mendiait à la porte d'une ferme, il arrivait neuf fois sur dix qu'on le menaçait de lâcher le chien après lui: s'il mettait le nez dans une boutique, on lui parlait du bedeau de la paroisse, et, à ce nom, il ne savait où se cacher.
}

${ }^{26}$ Não traduzido: lui donna du pain et du frommage. 
paragem remota do mundo, teve piedade dele e deram-lhe do pouco que tinham, com palavras tais que encheram a alma de Oliver.

$\mathrm{Na}$ manhã do sétimo dia chegou ele ${ }^{27}$ à pequena cidade de Barnet.

As portas ainda estavam fechadas e as ruas desertas ${ }^{28} \mathrm{o}$ sol estava brilhante; ${ }^{29} \mathrm{com}$ os pés em sangue e coberto de poeira, Oliveiro assentou-se nos degraus de uma casa.

Pouco a pouco foram-se abrindo as janelas e aparecendo gente que parava e olhava para Oliver, sem lhe darem nada. ${ }^{30}$

Havia já algum tempo que ele ali estava; admirava-se de ver tantas tavernas, porque a metade das casas de Barnet são tavernas grandes e pequenas; olhava distraído para os carros que passavam e admirava-se de que fizessem em algumas horas um trajeto em que ele gastara um semana inteira. ${ }^{31}$

Foi arrancado de suas reflexões por um rapaz que lhe passara pela frente pouco antes sem parecer vê-lo, e voltara e se colocara do outro lado da rua para o observar atentamente.

A princípio Oliveiro não the deu grande atenção; mas o rapaz ficou tanto tempo na mesma posição e lugar, que Oliveiro levantou a cabeça e olhou para ele.

Então o rapaz atravessando a rua e dirigindo-se para Oliver disse:

- Então que há, amiguinho?

$\mathrm{O}$ rapaz que lhe falava tinha quase a mesma idade que ele; era o indivíduo mais original que Oliver vira até então. Tinha o nariz arrebitado e torcido, ${ }^{32}$ a testa estreita, as feições comuns, e o exterior porquíssimo, o que não impedia que se mostrasse com ares de fidalgo. Era baixinho, tinha as pernas arqueadas e olhos sem vergonha; o chapéu estava posto na cabeça de modo que parecia prestes a cair; e efetivamente cairia se o pequeno não desse de quando em quando um movimento à cabeça para o repor na posição primitiva. Tinha uma casaca que lhe descia até aos calcanhares; trazia as mangas arregaçadas até os cotovelos, provavelmente com o

\footnotetext{
${ }^{27}$ Clopin-clopant.

${ }^{28}$ Não traduzido: et personne ne se rendait pas encore aux travaux de la journée.

${ }^{29}$ Não traduzido: mais son éclat ne servait qu'à faire voire au pauvre enfant toute l'horreur de sa misère et de son isolement.

30 "Sem lhe darem nada" traduz "ou se détournaient seulement en passant rapidement; mais personne ne le secourut, personne ne prit la peine de lui demander comment il était venu là: il n'avait pas le coeur de mendier, et il restait assis immoblie et silencieux".

${ }^{31}$ Não traduzido: avec un courage et une résolution au-dessous de son âge.

32 "Arrebitado e torcido" traduz "retroussé".
} 
fim de meter as mãos, como então fazia, na algibeira da calça de veludo. Calçava sapatos à Blucher. ${ }^{33}$

- Então, que há, amiguinho? Perguntou aquele misterioso rapaz.

- Tenho fome e estou muito cansado, respondeu Oliveiro com lágrimas nos olhos. Ando há sete dias.

- Sete dias! Disse o outro; Ah! Compreendo. Por ordem do bico? Oliveiro parecia admirado.

- Ignora acaso o que é o bico?

Oliveiro respondeu com singeleza que sempre cuidou que bico era boca de pássaro.

- Que inocência! exclamou o rapaz; um bico é uma autoridade policial; andar por ordem do bico é nunca andar direito, é andar às furtadelas. Esteve no moinho?

- Que moinho? disse Oliveiro.

- Que moinho! O moinho que anda sem água. Anda comigo; tu precisas comer; a bolsa não está muito recheada, mas enquanto houver... Anda, anda ${ }^{34}$ !

- O rapaz ajudou Oliveiro a levantar-se, levou-o para a loja de um sujeito que vendia velas, comprou aí um pouco de presunto e um pão de duas libras; meteu o presunto dentro do pão ${ }^{35}$ e foi com Oliver para uma sala que ficava no fundo de uma taverna.

Ali o misterioso rapaz mandou vir cerveja; a convite do seu novo amigo, Oliver atirou-se ao banquete e comeu com unhas e dentes, enquanto o companheiro o contemplava. Vou.

- Você vai a Londres? Disse o rapaz quando Oliver acabou. -

- Tem casa lá?

- Não.

O indivíduo entrou a assobiar e meteu as mãos na algibeira.

- Mora em Londres?

- Sim, quando estou em casa, respondeu o rapaz. Precisa de casa para passar a noite?

- Sim, desde que saí de minha terra ainda não dormi em nenhuma casa.

- Não te incomodes, ${ }^{36}$ disse o misterioso rapaz, eu devo estar esta noite em Londres, e conheço lá um velho respeitável que te

\footnotetext{
33 "Calçava sapatos à Blucher" traduz "Enfin, il était aussi fringant [avec ses brodequins à la Blucher] , que le fut jamais jeune homme de sa taille, c'est-à-dire de quatre pieds six pouces".

* Alude a um costume das prisões inglesas

34 "Anda, anda" traduz "Allons, debout sur tes quilles! Arrive".

${ }^{35}$ Não traduzido: pour qu'il fût à l'abri de la poussière, et plaçant le tout sous son bras.

${ }^{36}$ Não traduzido: pour si peu.
} 
dará casa de graça, com a condição que sejas apresentado por um dos seus amigos. Eu sou amigo dele. ${ }^{37}$

Dizendo isto, esvaziou o copo.

Jornal da tarde, 5-5-1870.

$$
* * *
$$

\section{NEBULOSAS}

Com este titulo acaba de publicar a Sra. D. Narcisa Amália, poetisa fluminense, um volume de versos, cuja introdução é devida à pena do distinto escritor de Pessanha Póvoa.

Não sem receio abro um livro assinado por uma senhora. É certo que uma senhora apode poetar e filosofar, e muitas há que neste particular valem homens e dos melhores. Mas não são vulgares as que trazem legítimos talentos, como não são raras as que apenas pagam de uma duvidosa ou aparente disposição, sem nenhum outro dote literário que verdadeiramente as distinga.

A leitura das Nebulosas causou-me a este respeito excelente impressão. Achei uma poetisa, dotada de sentimento verdadeiro e real inspiração, a espaços de muito vigor, reinando em todo o livro um ar de sinceridade e modéstia que encanta, e todos estes predicados juntos, e os mais que lhe notar a crítica, é certo que não são comuns a todas as cultoras de poesia.

Há, sem dúvida, alguma página menos aperfeiçoada, algum verso menos harmonioso, alguma imagem menos própria; mas, além de que esses senões melhor os conhecerá e me dará a autora com o tempo ( e um talento verdadeiro não deixa de os conhecer e emendar), é antes de admirar que o seu livro não saísse menos puro, dadas as condições de uma estreia.

Quisera transcrever aqui mais uma pagina das Nebulosas; receio estender-me demais; limito-me a dar algumas estrofes. Sejam as primeiras, estas que se chamam "Saudades", e que a leitora há de sentir o que são.

Tenho saudades dos formosos lares

Onde passei minha infeliz infância;

Dos vales de dulcíssima fragrância,

Da fresca sombra dos gentis palmares.

\footnotetext{
37 "Eu sou amigo dele" traduz "'avec ça que je n'en suis pas de ses connaissances!', ajouta-t-il en souriant pour montrer que ces dernières paroles étaient dites par ironie".
} 
Minha plaga querida! Inda me lembro

Quando, através da névoa do ocidente,

$\mathrm{O}$ sol nos acenava adeus languente

Nas balsâmicas tardes de setembro.

Lançava-me correndo na avenida

Que a laranjeira enchia de perfumes,

Como escutava tremula os queixumes

Das aguas na lagoa adormecida.

Eu era de meu pai pobre poeta,

$\mathrm{O}$ astro que o porvir lhe iluminava,

De minha mãe que louca me adorava

Era na vida a rosa predileta.

Mas...

... tudo se acabou. A trilha olente

Não mais percorrerei desses caminhos

Não mais verei os míseros anjinhos

Que aqueciam na minha mão algente!

Vê o leitor a harmonia destes versos, não menor nem menos suave que a destas estrofes da "Confidência", versos a D. Joana de Azevedo, de uma amiga a outra amiga:

Pensas tu, feiticeira que me esqueço,

Que olvido a nossa infância tão florida,

Que a tuas meigas frases nego apreço?

Esquecer-me de ti, minha querida?

Posso acaso esquecer a luz divina

Que rebrilha nas trevas desta vida? 
Sem ti não tem o sol um raio terno,

Contigo o mundo tredo - é paraíso,

E a taça do viver é mel eterno.

Oh! Envia-me ao menos um sorriso!

Dá-me um sonho dos teus dourados e belo!

Que um negro porvir além diviso,

Que a existência sem ti é um pesadelo.

São tristes geralmente os seus veros, quando não são políticos (que também os há bons e de energia não vulgar) : a musa da Sra. Narcisa Amália não é alegria; ela mesma o diz na poesia que intitulou "Sadness", e que transcrevo por inteiro e será essa a última citação:

Meu anjo inspirador não tem nas faces

As tintas coralíneas na manhã:

Não tem nos lábios as canções vivaces

Da cabocla pagã!

Não lhe pesa na fronte deslumbrante

Coroa de esplendor e maravilhas,

Nem rouba ao nevoeiro flutuante

As nítidas mantilhas.

Meu anjo inspirador é frio e triste

Como o sol que enrubesce o céu polar

Trai-lhe o semblante pálido - do artista

$\mathrm{O}$ acerbo meditar.

Traz na cabeça estema de saudades,

Tem no lânguido olhar a morbideza

Veste a clâmide eril das tempestades

E chama-se Tristeza.

Termino as transcrições e a noticia, recomendando às leitoras as Nebulosas. 
M.

Semana Ilustrada, no 629, 29-12-1872.

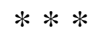

Meu caro Furtado Coelho,

Um grave incidente ocorrido a pessoa de minha amizade impediu que desse imediato cumprimento a tuas ordens, acrescendo que eu supunha marcada para sábado a representação e o dia é amanhã.

Acabo de escrever e remeto-te uns versos que me parecem servir. Emenda a desculpa e memória involuntária do teu

Machado de Assis.

22-11-76

" - Dize o que queres ! murmurava o príncipe!

- Tudo desejo, respondia a dama;

Eu quero as horas que o prazer inflama,

Eu quero as festas que aviventa o ardor.

Quero sentir na hora abrasadas pálpebras

A luz que traz o alvorecer do dia,

Quando começa o ressonar da orgia

E a voz expira ao turbulento amor.

- Minh'alma que queres? Perguntava o príncipe.

- Guarda tua alma, respondia a dama;

Esse amor puro que dos Céus é chama,

Se às virgens fala, não me fala a mim.

Eu sou a noite, a sedução, o estrépito,

Eu sou o mal, a agitação, a morte;

Guarda tua alma, que é de Deus consorte.

Dá-me teus lábios e o prazer sem fim.

(Biblioteca Municipal de São Paulo

Seção de manuscritos) 


\title{
A PROPÓSITO DOS DISPERSOS DE MACHADO DE ASSIS
}

\author{
Apesar dos esforços feitos pelo Instituto Nacional do Livro, particularmente
} do Sr. Alexandre Eulálio, a publicação do volume, prevista para 1963, foi adiada. Os Dispersos de Machado de Assis só viram a luz no final de 1965. Por essa razão, alguns elementos contidos no prefácio ou nas notas já foram modificados pelas pesquisas que viemos fazendo desde então. Aliás, essas questões serão retomadas na Biografia Intelectual de Machado de Assis que estamos preparando. O objetivo desta nota é corrigir algumas gralhas que prejudicam a boa utilização da obra, indicando também desde já alguns arranjos que o recuo de vários anos impõe. ${ }^{38}$

Tradução recebida em 25.11.2013 e aprovada em 09.12.2013.

\footnotetext{
38 P. IX 1. 36 ler Celle-ci; p. XI 1.38 ler Quatre textes encore pour 1870: la traduction d'Oliver Twist $8398)$ - p. XII 1.35 ler Ainsi 115 textes (118) - p. XIII 1.6 ler M.A. Calazans Peixoto. En tout 14 textes. - p. XIII 1.43 ler numéros: 76, 78, 82, 83, 85. Le n 81 - p. XIV 1.3 ler 136 - p. XV 1.2 ler Avant juger, pour juger - p. XVIII 1.2 ler peu connus - p. XIX supprimer 1.8 et ler était née aux Açores et qu'elle avait émigré au Brésil. Toutefois - p. XXIX ajouter l'indication bibliographique qui se trouve p. XXXI 1.5 et ler 59 au lieu de 56 - p. XXXIV 1.34 ler explique aussi - p. XL 1.17 ler 53 - p. XLI 1.33 ler ci-après - p. XLII 1.19 ler présence dans sa bilbiothèque.
}

P. 231.25 ler excelso2 - p. 311.3 ler Roucher - p. 341.34 ler procurai - p. 46 lers eulement A Marmota dans l'indication bibliographique - p. 48 I.12 ler VICTOR HUGO1 - p. 771.18 ler afogara p.102 I.4 ler sopro - p.103 ler 1.26 ler que aos azares do caminho - p.105 1.1 ler proscrits 4 -C'est - 1.2 ler odorant - p. 1331.16 ler TRAVESSA - p. 1781.20 ler Diva7 - p. 1811.19 ler chegaram - p. 182 1.20 ler patrióticos -p.206 1.4 ler Neves4 - p.208 1.12 ler praça2 et 1.14 ler Prata -p.236 1.4 ler futuras 8 - p.249 1.28 ler 108 - p-250 1.1 ler 106 - p. 2521.16 ler 14-8-1868 -p. 2521.17 ler 107 -p. 2761.2 ler chaminés - p. 3191.16 ler Sra. Bedwin et 1.25 ler caldo 13 - p. 3271.19 ler distraírem - p. 3311.42 ler tossiu - p. 3541.24 ler janela5 gradeada e 1.28 ler janela estava - p.381 1.39 ler chaleira2 -p. 3831.2 ler socorros3 - p.384 1.31 ler são6 e 1.35 ler são 6 - p. e1.35 ler são - p.389 1.11 ler doente11 e 1.16 ler doente -p. 4081.6 ler campo2 e 1.21 ler três3 - p. 452 ler CHOVENDO ${ }^{1}$ - P. 459 1.2 Ler BONS DIAS ${ }^{1}$ !

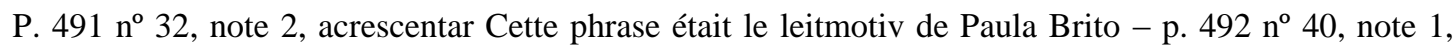
acrescentar La même épigraphe, mais plus étendue, avait déjà été empolyée par M. A. Álvares de Azevedo dans Vida. - p. 494 ler 44. A UMA DONZELA ÁRABE - p. 496 ler 47. A Partida e 48. A REDENÇÃO - p. 497 leia 49. BAGATELA - p. 499 lire 50. MOSAICO. S. HELENA - p. 502 leia 61. A DONA GABRIELA DA CUNHA - p. 519 acrescentar no fim do n ${ }^{\circ} 81$, nota 2, e em Obra completa de Machado de Assis, ed. Aguilar, t. III, pp. 987-988 - p. 526 ler 108. ADELAIDE RISTORI. E deslocar a nota - p. 561 acrescentar no 135 nora 1. CHOVENDO. Esse texto foi publicado com um título modificado em "Dia de chuva" por Raimundo Magalhães Júnior no volume Ideias e imagens de Machado de Assis, Rio, 1956, pp. 36-37 - p. 562 acrescentar n $^{\circ} 141$ nota 1 BONS DIAS. Esse texto foi publicado por Antonio Crispim no "Correio da manhã" 15-11-1958. 